TWO TAXATION AGENDAS: THE GALLOP GOVERNMENT'S

FIRST TERM

by

Michael McLure

Economics Program

School of Economics and Commerce

University of Western Australia 


\title{
Two Taxation Agendas: the Gallop Government's First Term
}

\author{
by \\ Michael McLure* \\ Economics Program \\ School of Economics and Commerce \\ University of Western Australia
}

\section{Introduction}

Fiscal management in Western Australia during the first term of Premier Geoff Gallop's Labor Government has been largely overseen by Mr Eric Ripper, the State's Treasurer, who delivered all four annual State budgets. Perhaps the main characteristic of this term of government has been the high propensity to increase taxes. However, it should also be recognized that a tax reform package was also introduced through the draft White Paper on Streamlining Western Australia's Taxation System.

This essay reviews the Gallop Government's revenue raising and tax reform agendas, and considers why these two agendas were not integrated in a united policy framework to improve the long term structure of the state taxation regime in the State. In particular, consideration is given to why, over the first three years of the term, large annual increases in the more inefficient and distorting state taxes, especially stamp duty, were being introduced when a separate tax reform package was being developed and enacted.

The main elements of the Government's tax reform agenda are reviewed in the first part of the essay. The major annual budget revenue raising measures, and the recent tax reductions announced immediately prior to the forthcoming state election, are reviewed in the second part. The likely reasons for the lack of strategic focus and integration between these agendas are discussed in the third part and are considered in the forth part. It is concluded that the Government did not integrate its two policy agendas because, at the commencement of its term, it had no expectation of emerging fiscal stress, or the likelihood of ongoing new tax measures to raise more revenue. When significant fiscal pressure emerged in the second and third budgets, the Government to took a 'reactive' and short term approach to tax measures that increase revenue, thereby confining the longer term perspective to its moderate tax reform package and maintaining a clear distinction between the two agendas. A viable strategic perspective on fiscal management did not emerge, and the opportunity to integrate the tax reform and the tax raising measures was lost. The recent tax reductions partially undo some of the 'reactive' and short term increases from the first three years of the Government's term.

\footnotetext{
${ }^{*}$ The author would like to thank Effie Giaros for research assistance on matters related to this essay.
} 


\section{The Reform Agenda}

In his very first budget (2001-02), Eric Ripper announced that the Department of Treasury and Finance would undertake a review of state business taxation (Government of Western Australia 2001, p32). This was undoubtedly inspired by a similar announcement a year earlier by the Government of Victoria, although the review processes, and the reviews' recommendations, were very different in character. ${ }^{1}$ The review report was delivered in early 2002 (Department of Treasury and Finance 2002) and by June 2002 the Government had issued a draft White Paper on Streamlining Western Australia's Tax System: Fewer Fairer and Simpler. It contained 31 recommended measures that alter revenue yield, including a commitment to abolish the Debits Tax from 1 July 2005, although this had been provisionally agreed by the previous government in the 1999 Intergovernmental Agreement on the Reform of Commonwealth-State Financial Agreements. ${ }^{2}$

In line with the recommendations of the draft White Paper, the State Government introduced substantial payroll tax reform, and also made significant changes to land tax and stamp duty. The multi-tiered payroll tax scale was replaced with a single marginal tax rate from 1 July 2003 and, from the same date, the 10 tiered land tax scale was also reduced to a 6 tier scale. Stamp duties on cheques, leases and unlisted shares were abolished from 1 January 2004 and stamp duties on workers' compensation insurance and life assurance were effectively abolished from 1 July 2004. A raft of minor changes was also introduced to improve administration, reduce avoidance and reduce compliance obligations and costs.

The previous payroll tax scale was designed to ensure that an employing firm's 'average' tax rate slides progressively from $0 \%$ (for firms under the exemption threshold) to $6 \%$ as the value of its payroll increases. However, by focusing on a smooth sliding average tax scale, undesirable side effects emerged, the most serious being the imposition of marginal rates as high as $11.6 \%$ across various moderate payroll value ranges, which then fell back to $6 \%$ for high value payrolls. Under this new single marginal tax scale, Western Australia was bought into line with most other states and the distortions from high marginal tax rates were removed, with payrolls either exempt from the tax because the value of a firm's payroll is below the exemption threshold, or subject to a $6 \%$ marginal rate on the proportion of the a firm's payrolls that is above the exemption threshold.

Beyond the payroll tax reform, the limited character of reform associated with the draft White Paper is very clear. In regard to land tax, the recommendation to reduce the number of tiers of the tax scale from 10 to 6 had no clear economic benefit. The measure was introduced to reduce the frequency of bracket creep. However, as the top marginal rate was not reduced and/or the bottom marginal rate increased to

\footnotetext{
${ }^{1}$ The contexts of the tax reform processes in Western Australia and Victoria, and a more detailed analysis the WA draft White Paper Streamlining Western Australia's Tax System: Fewer Fairer and Simpler, are considered in McLure (2002).

${ }^{2}$ The March 2004 meeting of the Ministerial Council on the Reform of Commonwealth-State Financial Agreements confirmed that all States will abolish the Debits Tax from 1 July 2005 (Costello 2004). Consequently, the forthcoming abolition is not considered further in this essay, as it is not unique to Western Australia and is really an initiative from the 1999 Intergovernmantal Agreement, and not the draft White Paper.
} 
'flatten' the tax scale, the cost to the taxpayer of a reduced frequency of bracket creep is a larger increase in the magnitude of the tax increase when bracket creep occurs. More fundamentally, the new land tax scale did nothing to diminish the tax penalty imposed on growing business that use taxable land intensively, and effectively provide a relative subsidy of economic activities that utilize very low value parcels of taxable land or very high value parcels on land exempt from land tax (such as land used for primary production or for owner occupied residences).

Imposing land tax on currently exempt land used for primary production and for owner occupied residences would afford the opportunity to introduce a single marginal tax rate scale, with a very low tax rate (i.e. fraction of a percent). The status of the draft White Paper as a reform document would have increased significantly if it has recommended changes to reduce and flatten the land tax scale while broadening the tax base, as this would have reduced the current disincentive for growth in firms that make extensive use of taxable land. Nevertheless, the difficulty of such fundamental reform is significant. The net effect would be to spread the legal obligation to pay land tax dramatically, with the number of taxpayers to face a 'moderate' tax increase (owners of low-valued taxable land) or a moderate land tax for the first time (owners of land used for primary production and residential homes) overwhelming the relatively small number of taxpayers who would face 'very substantial' reductions in land taxation. Given the voting system in Western Australia, with many owners of land used for primary production residing in rural regions with positive vote weighting, and the prospect of introducing land tax to voting home owners for the first time, realization of effective land tax reform is, perhaps, the most politically difficult of all state tax reforms.

Stamp duty is the most complex, but also the most archaic, of all state taxes. Therefore, it is not surprising that the greatest number of recommendations in the draft White Paper concerned stamp duty. Importantly, some of these are, in their own limited terms, positive reform measures. Most notably, there is the abolition of: very narrow and low yield duties (cheques, leases and unlisted shares); stamp duty which imposes unreasonable compliance costs (life insurance); and a stamp duty which is imposed on non-voluntary payments imposed via statutory obligation (workers' compensation insurance) $)^{3}$. However, these are all second order tax policy issues relative to the fundamental question of conveyance duty, which raises most revenue among all the stamp duties, and which has not been abolished.

Conveyance duty is the subject of eleven specific recommendations with revenue implications. The net effect of these changes was to increase the yield from conveyance duty by capturing a greater range of previous excluded transactions, most notably through the broadening of the scope of transactions that trigger the application of conveyance duty, such as share transactions to affect the transfer of a majority interest in private 'land rich' companies. In net terms, the changes to the tax base provided a broader foundation for increased reliance on conveyance duty. As increases in the rates of conveyance duty was also a feature of the Government's revenue raising agenda, the increased reliance on this tax is discussed in the next

\footnotetext{
${ }^{3}$ By the same criteria, the Government should also abolish stamp duty on compulsory third part insurance, although this was not recommended in the draft White Paper.
} 
section. Nevertheless, conveyance duty policy has proved to be the Gallop Government's single greatest fiscal and economic failure of its first term.

\section{The Revenue Raising Agenda}

Clearly the release of the draft White Paper marked a moment from a time consuming policy development and implementation process. The period from announcement of the review to the enactment of enabling legislation spans Eric Ripper's first three budgets (with some of the stamp duty measures only having an impact on state finances in the fourth budget). In view of this, the Government's reform agenda should not be considered as an isolated moment, but relative to other fiscal developments over the same period, particularly those pertaining to revenue matters. The most important single factor of the Government's fiscal policy is its increases in taxation over its first three budgets, and especially its ongoing tendency to treat conveyance duty as a sort of fiscal 'milch cow.'

It is clear that the revenue impact of the Gallop Government's budget tax measures is substantial. As shown in Table 1, the ongoing effect of taxation measures introduced over the Government's first three budgets accounted for around 13\% of state taxation revenue by the end of 2003-04, although this is expected to fall to an estimated 9\% in 2004-05 given the reductions in tax introduced in Eric Ripper's most recent budget.

\section{Table 1: ONGOING REVENUE IMPACT FROM FIRST TERM TAX MEASURES (a)}

\begin{tabular}{|c|c|c|c|c|c|}
\hline Tax Measures & & 2001-02 & $2002-03$ & 2003-04 & 2004-05 \\
\hline & & $1^{\text {st }}$ Budget & $2^{\text {nd }}$ Budget & $3^{\text {rd }}$ Budget & $4^{\text {th }}$ Budget \\
\hline Conveyance duty & $\$ \mathrm{~m}$ & 0 & 73 & 245 & 88 \\
\hline Other stamp duties & $\$ \mathrm{~m}$ & 0 & 64 & 123 & 113 \\
\hline Land taxes & $\$ \mathrm{~m}$ & 0 & 38 & 41 & 27 \\
\hline Payroll tax & $\$ \mathrm{~m}$ & 27 & 56 & 64 & 67 \\
\hline Other taxes & $\$ \mathrm{~m}$ & -4 & 38 & 46 & 42 \\
\hline \multicolumn{6}{|l|}{ Net Effect of Tax Measures } \\
\hline Amount Raised & $\$ \mathrm{~m}$ & 23 & 269 & 519 & 337 \\
\hline Proportion of all taxation revenue & & $1 \%$ & $8 \%$ & $13 \%$ & $9 \%$ \\
\hline
\end{tabular}

(a) Derived from the Appendix to this essay.

This pattern of new revenue-raising is consistent with the conventional understanding of the state's political-fiscal cycle: increased taxes in the first three budgets with reduced taxes in the final, pre-election, budget. However, the unusual feature of the Western Australian case concerns the high magnitude of the increases.

The main budget tax measures introduced by the Gallop Government outside of its White Paper reform framework are summarised in the Appendix to this essay. In 
its first budget, the Government's revenue raising measures were relatively modest, mainly increases in payroll tax rates and the base from 2000-01 and the increases in the land tax base from 2001-02. ${ }^{4}$ As the payroll tax base is relatively broad, the initial direct impact (some times called the legal incidence) was broadly based, initially impacting on a vast number of taxpaying employers, with the economic burden spread even more broadly through interdependent transactions directly and indirectly affected by this tax. The increase in the land tax base, by removing property held by companies and trusts from the principal place of residence exemption, could also be justified as a base broadening exercise. However, in the subsequent two budgets, the emphasis on tax measures drastically changed in two ways. First, the revenue raised from the tax increases was substantially higher. Second, the direct impact of the increased revenue raising was concentrated on stamp duties, most especially conveyance duty.

Importantly, conveyance duty is a very narrow property tax: it is not levied on all property owners, but only on those who acquire land and fixed capital, and is only imposed at the time of acquisition. Continued (and over) exploitation of this base represented a grab for additional funds predicated on the political 'line of least resistance' principle, whereby a relatively small subset of the community (i.e. those who purchase property) is deliberately targeted to pay most of the tax increase. Conveyance duty was increased by an average of $7 \%$ in the Gallop Government's second budget, and again by a massive $15 \%$ in its third budget. These rate increases were in addition to the extension of the range of transactions subjected to conveyance duty recommended in the draft White Paper.

The major problem with conveyance duty is that it, in effect, imposes a relative tax disadvantage on the acquisition and disposition of land and fixed capital, and a relative advantage on holding land and fixed capital. ${ }^{5}$ The increases in duty implemented in the second and third budgets served to significantly increase the tax disadvantage of acquiring capital, because the purchaser is legally liable for the tax. However, the economic cost of the more than $20 \%$ increase in conveyances duty is not limited to the purchasers of capital, because the duty also reduces the after tax price at which owners could dispose of their capital. In short, the increases imposed costs on both buyers and sellers of land and fixed capital, thereby reducing capital mobility. In addition, these rate increases result in consumers forgoing the benefits that they would have realised from increased productivity if the mobility of capital was not reduced by the increases in conveyance duty. Analogously, increases in conveyance duty rates have the potential to restrict labour mobility, which would also adversely impact on productivity and reduce benefits to consumers. ${ }^{6}$

\footnotetext{
${ }^{4}$ There was also talk of a new "premium property tax" imposed on residential properties, with a rate of $2 \%$ to be levied on unimproved values in excess of $\$ 1$ million. However, the Government withdrew this measure very quickly in response to strong public opposition (a decision which may well have been influenced by a forthcoming Federal Election).

${ }^{5}$ Some of these problems are discussed in Government of Victoria (2001), which recommends the abolition of stamp duties and their replacement with a flat low rate land tax.veyance .

${ }^{6}$ However, given the significant cyclical up-turn in housing prices over the term of the Government, it is unlikely that the increases in conveyance duty would have appreciably reduced labour mobility in Western Australia to date, although it may have an impact once growth in housing prices moderate or even decline.
} 
The Governments reliance on stamp duty as a means of raising additional revenue was not limited to conveyance duty. In his second budget, Eric Ripper also increased stamp duty on: compulsory third party insurance (from a specific rate of $\$ 0.25$ per policy, to an ad valorem duty in line with that applying to general insurance); and the transfer of motor vehicle licences. In the third budget, he increased the stamp duty rate on general insurance.

Insurance and vehicle ownership and transfers are reasonably broadly based, in that they move with general economic activity, and there is also a wide incidence of insurance and vehicle ownership. Consequently, the direct burden of these increases in rates of duty is legally spread broadly across the community. As a result, these measures were less harmful from an economic perspective than the increases in conveyance duty. Nevertheless, they are not an ideal form of tax increase. The increase in stamp duty on motor vehicle transfers can, like conveyance duty, act as a tax on the mobility of a productive capital asset (vehicles), and stamp duty on compulsory third party insurance may also be undesirable as a tax on a statutory charge. However, given the high incidence of vehicle ownership, these duties on vehicles could be viewed as a reasonable proxy for a 'household tax adjusted for capacity to pay' (as the incidence of car ownership greater in higher income households).

By the time of its fourth budget, the State government realized that it had come to rely far too heavily on conveyance duty. Consequently, it reduced rates of duty by $5 \%$ (compared to the $7 \%$ and $15 \%$ increases in the second and third budget's respectively) and exempted fist home buyers from the duty when the value of their home fell under a quite generous threshold. However, this appears to have less to do with a sudden revelation about the economic harm of conveyance duty than it does with other short term matters. Specifically, the unexpectedly long duration of the boom in the property market meant that 2003-04 conveyance duty revenue exceeded the budget estimate substantially - by $43 \%$, or $\$ 365$ million.

Even though the third budget was crafted with the intention of giving the Gallop Government a deep war chest for the forthcoming election (McLure 2003), it ended up being faced with an unexpected embarrassment of riches: the Government's 2003-04 operating surplus was an unexpected \$793 million - more than it desired when fighting the forthcoming election. In the prevailing pre-election environment, significant pressure has emerged for tax reductions ${ }^{7}$, and no shortage of advice from interest groups on how best to achieve this. As the Government had already delivered it final first term budget, the Premier (not the Treasurer) responded to this pressure by announcing new tax policies via media statement. On 27 October, Premier Gallop announced (Gallop 2004a) a reduction in the rate of payroll tax, falling from $6.0 \%$ to $5.5 \%$ to reduce revenue by around $\$ 110$ million per annum, and on 28 October, he announced (Gallop 2004b) a 10\% cut in rates of conveyance duty to reduce revenue by around $\$ 90$ million per annum. In addition, a conveyance duty exemption threshold for first home buyers was increased and average land tax rates were moderately reduced.

\footnotetext{
${ }^{7}$ Calls for tax relief were initiated by State Government backbenchers. The intensity and ad hoc nature of this pre-election debate over expected tax cuts is not an ideal environment for taxation policy matters to be considered in their long term perspective.
} 
Of course, the reduction in conveyance duty is to be welcomed. While rates of conveyance duty are still higher than at the beginning of Government's term, the reduction is nonetheless significant. However, the reduction in payroll tax appears to reflect erroneous policy prioritization. The Premier presented this as an initiative which will 'create more jobs' (Gallop 2004a). However, to the extent that the Government is motivated by a concern about private sector employment, consideration should be given to providing tax reductions that will create the most jobs. It is now well understood that the economic incidence of a broad based payroll tax is essentially the same at that for a broad based value added tax. ${ }^{8}$ Consequently, one needs to consider whether there is an over reliance on revenue from the aggregate of payroll tax and GST. However, even when the 10\% GST is recognized, it is still difficult to see positive long term employment effects from the reduced payroll tax rates exceeding those from new reductions in conveyance duty on 'business' transactions (along the lines foreshadowed in the 1999 Intergovernmental Agreement on the Reform of Commonwealth-State Financial Agreements).

\section{Failure to Integrate the Tax Reform and Revenue Raising Agendas}

Unfortunately, the Gallop Government did not adopt a strategic approach to taxation policy because it did not integrate its tax reform and revenue raising agenda, which would have facilitated the introduction of revenue raising measures which also contributed positively to a restructuring of the tax system. A wide ranging integrated package would also be likely to focus general public attention on the net cost or benefit of the entire package. In contrast, when the tax changes are presented as isolated revenue raising measures, public reactions tend to focus more on particular changes in isolation, which contribute to governments becoming timid of reform and very sensitive to the number of winners and losers from particular reform proposals. ${ }^{9}$

As noted earlier, the reform emphasis in Western Australia was, by-and-large, minimalist. With the notable exception of payroll tax, it focused on 'streamlining' to make administrative and compliance procedures more straight forward. To a large extent, this minimalist model was a consequence of failing to integrate the reform and revenue raising elements of State taxation policy. An important question then, is what factors acted against strategic thinking and broader tax reform? The two key factors appear to be the Government's: (i) failure to anticipate growth in operating expenses; and (ii) lack of flexibility when reacting to emerging fiscal stress, leading to a focus on short term 'revenue raising' fixes.

To establish a Government's capacity to strategically consider fiscal issues over one term in office, it is useful to compare the forward financial estimates from the first budget to the actual financial outcome. From Table 2, it is clear that, at the start of its term, the Gallop Government did not contemplate the large rises in operating expenses that eventuated.

\footnotetext{
${ }^{8}$ The GST does not tax firms' expenditure on capital goods, while a broad payroll tax does not tax firms' income from capital. In contrast to payroll tax, there are few popular calls to abolish the GST because it is a tax on employment. The merits of a payroll tax are examined in Crowe, M (1998).

${ }^{9}$ The Howard Government's A New Tax System is a notable exception.
} 
Table 2: GENERAL GOVERNMENT OPERATING EXPENSES

\begin{tabular}{|c|c|c|c|c|c|}
\hline Tax Measures & & 2001-02 & 2002-03 & 2003-04 & 2004-05 \\
\hline 2001-02 Budget: Forward Estimates (a) & $\$ m$ & 10,662 & 10,669 & 10,937 & 11,304 \\
\hline Actual Operating Expenses (b) & $\$ m$ & 10,813 & 11,548 & 11,960 & $\mathrm{n} / \mathrm{a}$ \\
\hline 2004-04 Budget: 2004-05 Estimate (c) & $\$ \mathrm{~m}$ & - & - & - & 12,447 \\
\hline \multicolumn{6}{|l|}{$\begin{array}{l}\text { Annual underestimate of operating } \\
\text { expenses in the 2001-02 Budget Estimate }\end{array}$} \\
\hline Amount of the underestimate & $\$ \mathrm{~m}$ & 23 & 269 & 519 & 337(d) \\
\hline Proportion of variation & & $1.4 \%$ & $7.6 \%$ & $8.6 \%$ & $9.2 \%(d)$ \\
\hline
\end{tabular}

(a) Source: Government of Western Australia (2001), p.2

(b) Source: Government of Western Australia (2002b), p.4 for 2001-02, Source: Government of Western Australia (2003b), p.5 for 2002-03, Source: Government of Western Australia (2004b) p.5 for 2003-04.

(c) Source: Government of Western Australia (2004a), p.1 for 2004-05.

(d) Compared to the 2004-05 Budget Estimate of operating expenses.

The consequences of this increase in expense emerges clearly when the Gallop Government's financial performance is considered against its own fiscal strategy, which is defined in reference to the following key financial targets: (i) maintaining an accrual operating surpluses for the general government sector; (ii) ensuring that public sector net worth does not decline; (iii) maintaining the net debt to revenue ratio at less than some fixed percentage; (iv) not increasing real per capita expenses; and (v) maintaining the State's tax competitiveness relative to other States. By the end of 2002-03, its second full financial year, the Government had failed to achieve the forth strategic target: real per capita expenditure increased. At the completion of 2003-04, its third financial year, the Government failed to achieve the fourth strategic target for the second year in a row and, importantly, also failed to achieve it fifth target: Western Australia's ranking of State tax competitiveness declined.

Therefore, the Government did not initially integrate development of its tax reform and revenue raising measures from the start of its term because it did not have a strong expectation of any need for new tax measures. In reacting to unanticipated fiscal pressure from growth in expenses, it can be inferred that the Government gave greater priority to maintaining the net debt to revenue ratio than to maintaining the State's tax competitiveness, probably because maintaining the State's good credit rating is more sensitive to the net debt to revenue ratio, than tax competitiveness. This prioritization of strategic fiscal benchmarks makes some financial, and also political, sense, as a downgraded credit rating is often considered as an independent judgement of poor fiscal management.

As an emerging problem with growth in expenses was evident as early as 200203, the pressure to increase state taxes was intensified by the Government's commitment to maintaining a high credit rating. However, the Government's tax policy reaction to this fiscal pressure was not strategic, but rather determined by short term considerations that resulted in annual stop-gap measures introduced without full regard for either: (i) the medium term tax policy implications of on going growth in expenses; or (ii) the long term tax policy implications of the tax response to fiscal stress. This provided the context in which the Government's dual tax agendas emerged as distinct programs. Having set this framework in its second budget, the Government followed it again in its third budget, again emphasizing quick stamp duty 
fix to raising more revenue in 2003-04, although this time it overdid it, raising more than it needed. The end result was that the limited reform agenda slipped quietly into the background, while the reactive and ad hoc revenue raising tax measures in Eric Ripper's second and third budgets coming to dominate perceptions of the Gallop Government's taxation policy.

\section{Conclusion}

On taking office, the Gallop government had no real expectation of introducing the significant revenue raising tax measures which became the defining characteristic of its first term fiscal policy. Consequently, the possibility of integrating tax raising and tax reform agenda was simply not an issue at the start of its term. However, as early as its second financial year, the revenue budget came under considerable pressure from unanticipated growth in general government operating expenses and the desire to maintain a good credit rating. In reacting to this, the Government embarked on revenue raising tax measures that were little more than short term solutions. Shortly after this, the Government released its draft White Paper on tax reform, which was implemented as a distinct and separate agenda.

Consequently, the Government's reaction to fiscal stress was dominated by the considerations related to the balance of the annual budget. Over time, the reform agenda, which was driven by medium and long term considerations, diminished in importance and the ad hoc revenue raising agenda grew in importance. This proved costly in both economic and political terms. It was costly in an economic sense because policy was dominated by short term, rather than medium and long term, considerations, with the potential to integrate tax reform and tax raising measures being lost in favour of the over-reliance on conveyance duty. It was also costly in a political sense because the Government's large and unbudgeted operating surplus in 2003-04 was, to a considerable extent, due to an underestimation of receipts from conveyance duty. While the fourth budget was marked by a moderate reduction in conveyance duty rates, which in itself was something of an embarrassing back-flip, the Government soon faced an awkward pre-election predicament. It has the fiscal capacity to commence significant reform of the tax system, but to do so would require it to (further) undo its own earlier increases in conveyance duty. Fortunately, the Government recognized the problem and moved to further reduce conveyance duty in a pre-election media release. 
APPENDIX

\section{Budget Tax Measures of the Gallop Government}

Tax Measures (a)

Conveyance duty

2002-03 Budget: Increase rates of duty by average of 7\%

2003-04 Budget: Increase rates of duty by $15 \%$ across the board 2004-05 Budget: Decrease rates of duty by 5\% across the board 2004-05 Budget: Introduce exemption for first home buyers

Net effect of changes to stamp duty on conveyance

$\begin{array}{cccc}2001-02 & 2002-03 & 2003-04 & 2004-05 \\ \$ \mathrm{~m} & \$ \mathrm{~m} & \$ \mathrm{~m} & \$ \mathrm{~m}\end{array}$

$\begin{array}{cccc}0 & 73 & 88 & 65 \\ 0 & 0 & 157 & 116 \\ 0 & 0 & 0 & -47 \\ 0 & 0 & 0 & -46 \\ \mathbf{0} & \mathbf{7 3} & \mathbf{2 4 5} & \mathbf{8 8}\end{array}$

\section{Other stamp duties}

2002-03 Budget: Increase stamp duty on CTP insurance 2002-03 Budget: Alter rates of stamp duty on vehicle licences 2003-04 Budget: Increase rate of duty on general insurance Net effect of changes to other stamp duties

$\begin{array}{cccc}0 & 27 & 30 & 28 \\ 0 & 37 & 42 & 39 \\ 0 & 0 & 51 & 46 \\ \mathbf{0} & \mathbf{6 4} & \mathbf{1 2 3} & \mathbf{1 1 3}\end{array}$

\section{Land taxes}

2001-02 Budget: Remove residential exemption for trusts 2001-02 Budget: Premium property tax - not implemented 2001-02 Budget: Increase tax rates by average of $11 \%$ 2004-05 Budget: Adjust tax rates

Net effect of changes to land tax

\section{Payroll tax}

2001-02 Budget: Increase rate tax rates and base increase 2002-03 Budget: Some base broadening not implemented Net effect of changes to land tax

$\begin{array}{cccc}0 & 10 & 11 & 12 \\ 0 & 0 & 0 & 0 \\ 0 & 28 & 30 & 32 \\ 0 & 0 & 0 & -17 \\ \mathbf{0} & \mathbf{3 8} & \mathbf{4 1} & \mathbf{2 7}\end{array}$

$\begin{array}{cccc}27 & 62 & 70 & 74 \\ 0 & -6 & -6 & -7 \\ \mathbf{2 7} & \mathbf{5 6} & \mathbf{6 4} & \mathbf{6 7}\end{array}$

\section{Other taxes}

2001-02 Budget: Range of relatively minor tax measurers

$\begin{array}{lll}-4 & 38 & 46\end{array}$

42

(a) Excludes reform measures associated with the draft White Paper. Estimates for each category of taxation are from the budget papers in the year in which each measure was announced (Source: Government of Western Australia, 2001, 2002a, 2003a, 2004a), adjusted for reported variations between the 'estimated' and the 'actual' revenue (Source: Government of Western Australia 2002b, 2003b and 2004b for 2001-02, 2002-03 and 2003-04 respectively) or the latest available estimate in the case of 2004-05 (Source: Government of Western Australia 2004a). This is projected forward annually as a fixed proportion of the actual 
References

Costello, P., Treasurer of the Commonwealth of Australia (2004), Press Release No. 016: Meeting of the Ministerial Council for Commonwealth-State Financial Relations and Outcome of the Australian Loan Council, released 23 March 2004, <http://www.treasurer.gov.au/tsr/content/pressreleases/2004/016.asp > accessed 18 October 2004.

Crow, M. (1998) “A Case for Payroll Tax", in State Taxation: Repeal, Reform or Resignation, Proceedings of the ATAX Conference, 11 June 1998, University of New South Wales, Sydney, pp.1-21

Department of Treasury and Finance (2002) Review of State Business Taxes, Department of Treasury and Finance, Perth.

Department of Treasury and Finance (2004) Overview of State Taxes: Western Australia 2003-04, Department of Treasury and Finance, Perth.

Gallop, G., Premier of the State of Western Australia (2004a), Media Release: Gallop Government Announces cuts in Payroll Tax and Red tape", released 27 October 2004, <http:/Www.mediastatements.wa.gov.au/media > accessed 5 November 2004.

Gallop, G., Premier of the State of Western Australia (2004a), Media Release: State Government Announces Stamp Duty and Land Tax Cuts", released 28 October 2004, <http://www.mediastatements.wa.gov.au/media > accessed 5 November 2004.

Government of Victoria (2001) Better Business Taxes: Lower, Fewer, Simpler, Department of Treasury and Finance, Melbourne.

Government of Western Australia (2001) Budget Paper No.3: Economic and Fiscal Outlook 2001-02, Government Printer, Perth.

Government of Western Australia (2002a) Budget Paper No.3: Economic and Fiscal Outlook 2002-03, Government Printer, Perth.

Government of Western Australia (2002b), Government Financial Results Report 2001-02, Government Printer, Perth

Government of Western Australia (2002c) Streamlining Western Australia's Tax System: Fewer, Fairer and Simpler, Department of Treasury and Finance, Perth.

Government of Western Australia (2003a) Budget Paper No.3: Economic and Fiscal Outlook 2003-04, Government Printer, Perth.

Government of Western Australia (2003b), Government Financial Results Report 2002-03, Government Printer, Perth 
Government of Western Australia (2004a) Budget Paper No.3: Economic and Fiscal Outlook 2004-04, Government Printer, Perth.

Government of Western Australia (2004b), Government Financial Results Report 2003-04, Government Printer, Perth

McLure, M (2002) “Streamlining Western Australia's Tax System", Western Australian Quarterly Economic Briefing, 2.02, pp.47-59.

McLure, M (2003) "Gallop's Regime is Overdoing its Duty", Australian Financial Review, 12 May 2003, p.55

State Business Review Tax Committee (2001) Review of State Business Taxes: Summary Report, Department of Treasury and Finance, Melbourne 